\title{
THE STATUS OF AGRICULTURAL LABOR
}

\author{
WILLIAM T. HAM*
}

It has long been customary to regard the farm laborer, not as an ordinary employee, but as a farmer's apprentice. Often he was a neighbor's son or a thrifty, hardworking immigrant from northern Europe. Farmers complained that as soon as he became really useful he left for a farm of his own. This was the only labor problem. Today, however, in some quarters, this view is held to be quite obsolete. The farm laborer is described as an economic half-caste, cut off from any chance at ownership and denied even the meagre legislative protection which is given the worker in industry. For the picture of the hired man eating at the farmer's table is substituted that of a group of ignorant Mexican field hands camped by a ditch at the roadside.

The status of the farm hand on the "agricultural ladder" is truly a matter of significance. If the laborer is a tenant in the making, his conditions of employment are of less importance than if he is destined to remain a laborer for life. It has been said that it is doubtful if, in this country, farm wages ever have been high enough to warrant any man deliberately adopting farm labor as a life occupation,-that, as a matter of fact, wages have ordinarily been only part of the remuneration, the rest consisting of training in the business of running a farm. ${ }^{1}$ More recently, however, it has been asserted that the agricultural ladder has become difficult, if not impossible, to climb. Many tenants and small owners, debt-burdened, have become laborers. The proportion of owner-operators of farms has decreased while that of tenant operators has increased. It is suggested, moreover, that in such movement through tenancy to ownership as does occur, the rate of ascent has of late been much retarded.

The correctness of the interpretation of the census figures in terms of a permanent stratification of tenure status is open to question. However, it is clear that there has been a piling up of farm laborers at the base of the tenure structure. This is a development which has accompanied the trend toward the more intensive use of agricultural resources. In different parts of the country, from 1880 to 1930, changes

- A.B., College of the Pacific; A.M., Stanford University; A.M., Ph.D., Harvard University. Fellow of the Social Science Research Council, 1927-9. Assistant Professor of Economics, Harvard University, 1931-5; Chief Code Adviser, Labor Advisory Board, N. R. A. At present Chicf of the Tenure and Labor Relations Section, Division of Program Planning, Agricultural Adjustment Administration.

${ }^{1}$ Black, Agricultural Reform in the United States (I929) 445-446. 
in the tenure groupings have varied. The shift from grain growing to dairy farming in Minnesota and Wisconsin, and to corn-hog and beef cattle farming in Iowa, brought a decrease in the proportion of owners and an increase in that of tenants and laborers. In Kansas, the partial shift from small grain to corn and livestock brought with it a relative increase in the labor supply. In Ohio, there was relatively little change. California and New Jersey, however, as a result of the growth of truck, fruit, and poultry enterprises, exhibited a starting increase in the proportion of laborers at the expense of that of owners and tenants. ${ }^{2}$

In the South the tenure structure was modified in a different manner. In Alabama and North Carolina, for example, the proportion of tenants increased while that of owners and laborers decreased. The laborers evidently had become share croppers. Whether this is to be regarded as a step up the agricultural ladder in any significant sense is doubtful. To southerners, the cropper is merely a laborer who is paid through a share in the crop. However, this shift undoubtedly is the explanation of much of the growth of tenancy in the South reported in census figures. From r930 to 1935 the number of croppers declined-a development which is likely to continue. Whether the proportion of farm laborers will increase correspondingly remains to be seen, since in the plantation areas the ultimate effects of mechanization and of measures for the control of the volume of cotton production are as yet indistinct.

In considering the status of farm labor, it may be well at the outset to point out that, although there is a current tendency to center the discussion upon the migratory seasonal laborers, there are in fact three fairly distinct classes of farm workers. The first of these consists of unpaid members of the farm family, who, on the typical American farm, still do most of the work. In r929, out of a total of $6,288,648$ farms covered by the 1930 agricultural census, $58 \%$ hired no labor. The number of unpaid family workers was given in the 1930 census as $1,659,792$; in 1935 the agricultural census reported 4,273,166 such workers. In American agriculture only about one fourth of the gainfully employed are hired persons; in industry wage workers form the bulk of the working force. The economic maladjustments of the unpaid family workers, while constituting an important phase of farm welfare, are seldom alluded to in connection with the labor problem.

The second major group of farm laborers is that of the regular helpers, hired for all or for a good part of the year. According to the I5th census there were, on April I, 1930, 2,732,972 persons whose usual occupation was working on farms for wages. In the agricultural census of 1935, of the 967,594 farms which reported hired help, 722,645 had only one employee, 137,670 had two, while only II,410 reported to or more wage hands. It is clear, therefore, that the persons in this second group of farm laborers are widely dispersed. There is little reference to them in the writings on the grievances of farm labor, and it is safe to say that in most areas they do not represent a serious labor problem. They are characteristic of the regions given over

\footnotetext{
"Black and Allen, The Growth of Farm Tenancy in the United States (May I937) 51 Q. J. Econ. 402-405.
} 
to production of corn and livestock, wheat and the small grains, of the dairying districts and the western range.

Concerning the third group, namely, the casual and seasonal farm laborers, resident and migratory, no satisfactory census information is available. In view of the fact that in some specialized areas agriculture is largely dependent upon them, the lack of data is unfortunate. Moreover, it is the employment status of this group and, more particularly, of the estimated quarter of a million migratory workers, that most frequently gives rise to charges of exploitation of farm labor. Around the citrus workers in California and Florida, the vegetable workers in New Jersey, the Texas cotton pickers, the lettuce field hands of the Imperial and Salinas Valleys and the beet workers in Colorado and Michigan, there has grown up an extensive literature of complaint, some dating back to the first decade of this century. Estimates of the total number of the part-time seasonal laborers range from one to two million.

It is of interest to note that while, since the turn of the century, there has been an increase in the number of employees in industrial undertakings, in agriculture, despite an increase, probably of more than a third, in total farm output, the number of hired laborers in $193^{\circ}$ was not very different from what it was in 1900 . In some states it is true that farm workers make up a significantly greater proportion of the persons gainfully employed in agriculture than was the case in earlier years. In these areas there has usually been an increase in the number of large scale farming enterprises. A census investigation listed 7,875 of these in 1929 out of a total of $6,288,648$ farms in the United States. They represented about $0.1 \%$ of all farms and less than five per cent of American agriculture, being concentrated in truck, fruit and stock ranch areas. ${ }^{3}$ It thus appears that, even if the large enterprises made up of several operating units under unified control and the plantations of the South were included in the count, large scale farms are not, in general, characteristic of American agriculture.

T $\alpha$ say this, however, is not to belittle the importance of the seasonal farm labor problem in those areas where large scale and intensified production of special crops has become common. In I929 there were in California 2892 large scale farms and $73 \mathrm{I}$ in Texas, as compared with $6_{5}$ in Iowa and 21 in Minnesota. Of the large scale enterprises in truck crops California had $59.7 \%$, in fruit $60.1 \%$, in cotton $30 \%$, in dairying $40.5 \%$, and in poultry $52.9 \%$. In this state in 1930 agricultural wage earners made up $56.4 \%$ of the total gainfully employed agricultural population ro years of age and over, as compared with a percentage of 26 for the United States. These figures indicate a development in agricultural organization quite different from the old-fashioned family unit, which, when coupled with the growth of auxiliary canning and packing industries, with their highly seasonal demands for relatively unskilled laborers, gives rise in limited areas to a labor problem of peculiar difficulty.

One of the most striking features of farm employment is the varied character of the demand for labor. This comes not only from the varied labor requirements

\footnotetext{
s Jennings, Large-scale Fariang in the United States, $x 929$ (I933) 7.
} 
of different crops, but also from the variations in the requirements of the same crops in different areas. In the Corn Belt, for example, corn harvested from standing stock requires $\mathrm{x} 9$ man hours per acre, while further east, an acre of corn cut and harvested from shock requires 53 man hours. ${ }^{4}$ In California there are produced on a commercial basis 213 field, fruit, and truck crops, 2I types of livestock products, II types of poultry products, and a score of miscellaneous commodities such as honey, queen bees, fox furs, trout, mushrooms, nursery stock, bulbs, and cut flowers. The small grains in Contra Costa County require only 25 man days of seasonal labor per I000 acres annually, while the hops in Butte County call for 5I,000 man days per 1000 acres. In such special crop areas, the basic labor problem is the need for a supply of workers during certain seasons which is greater than can be profitably employed by agriculture throughout the year. In California, for every roo seasonal workers required in the winter period, 172 are needed during the early summer and 227 during the fall. During the month of March a minimum of 48,000 seasonal workers is required, for February, 50,000, for December, 56,000. From this one might conclude that agriculture in California offers year-round employment for 48,000 workers, employment for II months for 2,000 more and so on. As a matter of fact, however, even 48,000 workers cannot be given year-round employment because of the various tasks required and because of the wide separation of the areas which offer employment. ${ }^{5}$

The demand for farm labor has been greatly affected in some areas by the mechanization of farm operations and in the future is likely to be still further modified thereby. During the first quarter of this century it was the annual harvest migration in the wheat belt which furnished the most familiar example of migratory seasonal labor. In some years as many as 250,000 men were called for to shock and thresh the grain. With the coming of the tractor combine, however, this migration became a thing of the past. In other portions of the United States the increase of tractor, motor truck and motorized tillage equipment had similar, if not as drastic, effects. In $1920,15.2 \%$ of the farmers of the country had tractors, in $1930,43.8 \%{ }^{\circ}$ In the South, the increase has been less rapid, but there concern is expressed as to what may happen if success is met with in the efforts to perfect a mechanical cotton picker and to extend methods of check-row planting and cross cultivation as a means of decreasing chopping by hand. In Texas, Arizona, and California, the result may be that the migratory labor, now widely used in these regions, to the practical exclusion of sharecropping, may be eliminated. In the eastern cotton area, where hand labor requirements are met by the share croppers with their large families, the effects of mechanization are likely to be still more serious. A similar displacement

\footnotetext{
'Moorhouse and Juve, Labor and Material Requirements of Field Crops, U. S. DeP'T Agric, BuLd. 1000 ( $193 \mathrm{r}$ ).

-Adams, R. L., Farm Labor, a paper presented at the annual meeting of the Western Farm Economics Ass'n, June, r937.

- Cooper, Displacement of Horses and Mules by Tractors (June r937) The Agricultural Situation (U. S. Dep't Agric.) 22-23.
} 
of labor may take place in the sugar beet fields, with the development of mechanical methods of thinning and harvesting.

From the census it appears that in I930 the hired workers on American farms, outside of the South, were predominantly native born, white men. Only. among Negroes was there a large proportion of female workers. Children form an appreciable part of the labor supply only in the South and in the special crop areas. In 1930, despite the limitations on immigration, a considerable number of the farm hands were foreign born. The significance of this group is greater than their numbers indicate, for it is these people, in particular, who are likely to be found in the specialized areas. In California, the gradual intensification of agriculture has involved the use, first, of Chinese, then of Japanese, then of a mixture of racesArmenians, Portuguese, Italians, German-Russians, East Indians and Negroes-and finally of Mexicans and Filipinos. Foreign-born farm hands of an older generation in New England, Michigan, and Wisconsin often dispossessed the native-born farmers and drove them to urban employments. In Colorado and Nebraska, many German-Russian sugar beet workers have become farm operators. The present-day Mexicans, Filipinos, and South Europeans, however, do not seem, as a group, to better themselves.

Owing to the scattered, seasonal and highly diversified nature of much agricultural labor and the varied wage arrangements, information on wage rates and earnings is much less satisfäctory than in the case of the major groups of industrial workers. However, the available data since rgro show that farm wage rates have maintained a fairly consistent relationship to farm income, gross and net, also to prices received by farmers for their products and to other such factors. This would seem to indicate that farm wages in general do not rest upon the irresponsible caprice of the farm operator, but, in the large, bear a definite relationship to the economic enterprise of farming. Farm wage rates fluctuate less and change more slowly than farm incomes. In 1929 farm prices and incomes were at a level which was about $150 \%$ of the prewar standard, and farm wage rates at about $170 \%$, as compared with a level of about $230 \%$ of the prewar level for urban wage rates. The competition of industrial employments, at high wages, thus supported a level of farm wage rates which was high relative to farm prices and farm incomes. In 1932 farm prices and farm income per capita fell to nearly one-half of their prewar averages, while farm wage rates were slightly below their prewar level. In 1933, when farm incomes turned upward, farm wage rates lagged and have remained in a position of relative disadvantage, due, no doubt, in part, to the inability of farm laborers to shift, as during the post-war period, to industrial employments. Reduction in demand owing to increased mechanization is also a factor. As a result, farm wage rates at present, although at about the same level as farm prices relative to their prewar averages, are low by comparison with post-war standards of farm prices, farm incomes, and urban wage rates. The outlook for improvement depends upon such factors as normally, in the past, have reduced the hangover supplies of farm labor, 
viz., enhanced industrial recovery, with growth of urban purchasing power and increased offering of urban jobs. At present, the recapture of our export trade in cotton, wheat, etc., and control of the rate of mechanization of farm operations are factors of importance.

Geographically considered, in July, 1937, average monthly farm wage rates with board varied from $\$ 16.70$ in the East South Central states to $\$ 46.49$ on the Pacific Coast, as compared with $\$ 23.80$ and $\$ 53.10$ during the period r925-29. The ranking of the geographical divisions follows roughly the ranking in gross and net farm incomes. ${ }^{7}$ Widely differing suggestions have been made as to the reasons for this regional variation; it must suffice to say that it appears to be due to differences in the effectiveness with which productive resources and equipment are used in relation to man power. Such factors as the presence of industrial competition for labor, the opportunity for some degree of permanence of employment, the efficiency of the laborers and their standards of living also have influence.

Any cursory examination of the farm labor problem must necessarily omit consideration of the wide variety in methods and forms of wage payment-time and piece rates, summer and winter rates, bonuses and holdbacks, payments by token and through provision of board and lodging, perquisites and allowances in kind, credit and commissary arrangements,-which so often furnish opportunity for friction in employment relations. In industry, cash wages prevail and variations are likely to apply to a considerable number of workers. In agriculture, on the other hand, perquisites make up nearly two-fifths of the wages of non-casual hired farm hands the country over and their nature may vary from farm to farm. Perquisites are ordinarily defined as emoluments given in addition to wages at the going rate. In agriculture, however, they are looked upon by both worker and employer as emoluments in place of cash wages, the two together constituting total wages. Perquisites may include a wide range of goods and services, such as board and room, housing, dairy and meat products, flour and meal, and various privileges such as that of keeping livestock, with feed or pasturage. The precise combination is determined by custom. The items board, room, and washing are of greatest importance; in 1925 they averaged $\$ 26.65$ per month in value in the case of the noncasual hired farm laborer. Housing and fuel, second in importance, averaged \$12.12 per month per worker of the same group. Casual laborers received less in way of perquisites than the regular workers, but even here such items amounted to nearly one-fourth of the total remuneration. ${ }^{8}$

The complexities above referred to make it difficult to compare the level of agricultural wages with that in industry. On the one hand, we have the judgment of such an authority as Paul $\mathrm{H}$. Douglas, who in his Real Wages in the United States concludes that since I8go the absolute level of farm wages has been low when

'Black, Agricultural Wage Relationships (1936) I8 Rev. OF Econ. Statistics, No. 2.

${ }^{8}$ Folsom,-Perquisites and Wages of Hired Farm Laborers, U. S. Dep'T Agric. Tech. Bull. 213 (193I) $\div 2$. 
compared with the wages of the city workers and that, despite the high cost of living in the cities, hired workers found better opportunity there than in the country. ${ }^{9}$ On the other hand, however, we have the view that if the wages of farm laborers, including perquisites, are compared with those of unskilled common laborers in industry, the former equal or exceed the average full time and actual earnings for common laborers in representative industries. ${ }^{10}$

The effects of the intermittent employment that is characteristic of agriculture are shown at their worst in the case of the migratory farm laborers in the special crop areas. Their number has been estimated at anywhere from 200,000 to 350,000, with as many as 150,000 in California. ${ }^{11}$ In that state, the beaten track runs from the peas, lettuce and cantaloupes of the Imperial Valley through the San Joaquin, with its cotton, grapes, and fruits of various kinds, to the Sacramento Valley in the north, -a direct distance of over 500 miles. Many migrants go much further,-to the berry harvests of Puget Sound, the apple harvests of Hood River, Oregon, and Yakima, Washington, or those of peas or beets in Idaho, Montana, or Colorado. Cotton pickers in California may come from Arkansas; those in Oklahoma may have begun the season's work 600 miles away in south Texas. Berry pickers do not ordinarily travel so far but one established toute of travel is from Louisiana to Michigan. Many workers in the citrus, fruit, berry and truck crops of Florida come from Georgia or Alabama.

The old time harvest hand was a single man. Today the migratory worker is often accompanied by his entire family, which, with the few belongings, are crowded into an old car. On the larger farms he may find good housing accommodations, with facilities for securing supplies. For the mass of the migrants, however,.camping accommodations are of the most primitive and unsatisfactory sort and are a constant menace to the health of the community. Lacking a fixed residence, the migrants find relief difficult to get, owing to the settlement laws. Harsh measures are frequently employed by authorities to prevent their entry or to hasten their departure.

The children of the migrants give rise to a perplexing problem. Under conditions of normal and permanent residence in a community or on a farm, such farm work as children are ordinarily required to do cannot be regarded as harmful. In the South child labor is but one expression of widespread rural poverty. In the special crop areas, however, the problem is of a peculiar character, due to the constant movement of the migrant families and the lack of alternative activities for the young. The earnings of children form an important contribution to the family income, hence the difficulty of keeping them out of the fields. But even if this were

\footnotetext{
- Douglas, Real Wages in the United States (1930) i89-90.

${ }^{20}$ Folsom, op. cit. supra note 8,55 . Recent data as to total annual earnings relate to seasonal workers, chiefly relief clients. See Webb, The Migratory Casual Worker, W. P. A. ResenRch Monograph VII, (1937) 67-70. Landis and Brooks, Farm Labor in the Yakima Valley, Wash. Agric. Exp. Stat. BuLI. 343 (1936) 54, report a median annual income of heads of transient families of $\$ 297$ and of heads of resident families of $\$ 198$.

"Taylor, Migratory Farm Labor in the United States (March 1937) 44 MONTHLY LABor REv. 546. 
possible, in most states there are no educational facilities. School regulations, in the case of migrants, are not enforced. The children are not welcome in the schools of a community. Educationally retarded, undernourished and often diseased, deficient in moral training, unused to school procedure, they are usually a disrupting element. In California much effort has been devoted to this problem and special facilities for the migratory children have been provided. Even here, however, in the districts where attendance laws have been fairly well enforced, the ill effects of the constant shifting from school to school remain.

As regards employment relations, in the major corn, wheat, livestock, and general farming areas, where the hired man deals directly with the farmer and often works beside him, there is little occasion for complaint as to management and supervision. At harvest time, it is true, where the machine has not displaced the itinerant laborer, there still appears some of that suspicion and hostility between farmer and men which in the past was so fertile a field for the I. W. W. propaganda. Also, in the dairying regions, among milkers and truckmen, there have been diffculties. But it is in the special crop areas, again, in connection with seasonal, migratory labor, that the nearest approach in agriculture to the management problems which obtrude themselves in packing house and cannery is found. The complaints are varied. They relate to the haphazard methods of recruiting labor, to reliance upon the "labor contractor," not only for a supply of workers but for field supervision and payment of wages, to manipulation of piece rates and the use of speed-up devices, fake "bonuses," and "hold-backs." The reluctance of growers to deal with a union in determining wage rates, or even to discuss the matter with employees, is also a common grievance.

As a response to unsatisfactory conditions of employment, agricultural laborers in this country and abroad have attempted to secure for themselves the benefits of collective bargaining. Aside from the ill-fated efforts of the six Dorchester laborers in 1834 , probably the first significant venture of this kind was the union established by the Englishman, Joseph Arch, in 1872, the forerunner of the National Union of Agricultural Workers. In pre-Nazi Germany there was an interesting development of agricultural trade unionism dating from rgo8. The International Landworkers Federation, at its 7 th Congress in 1935, comprised agricultural workers' unions of 20,000 members or more in six countries, as well as smaller bodies in five others.

Everywhere it has been the experience that agricultural unions are difficult to organize due to the fact that workers are ordinarily not concentrated, like industrial workers, under one roof but are widely scattered. Moreover, the regular farm hand, like the farmer, is usually a conservative person, while the seasonal workers, often of alien origin, are unstable and likely to be impatient with the slow procedures of organization and bargaining. A union, once organized, is not easy to maintain. The dispersion of the workers calls for numerous small locals, for a number of officials and an outlay of time and money that are disproportionately large by comparison with unions of industrial workers. Frequent meetings are not easy to 
arrange and propaganda is costly. Moreover, union dues represent a relatively larger drain upon the cash resources of the agricultural than of the urban worker.

In the United States, the difficulties are greater than in such comparatively compact and racially homogeneous countries as England and Germany. And yet, during the past $3^{0}$ years, there has been a succession of efforts at organization, especially among seasonal workers. The first attempt was that of the I. W. W., in 1909. After the War, the venture was continued by the Communists and various brands of "left wingers." From time to time the A. F. of $L$. and some of its affiliated state federations made tentative forays into this field. In I933, there was an outbreak of agricultural strikes in the special crop areas and efforts to form unions were redoubled. In 1936 there were affiliated with the A. F. of L. some 62 agricultural and cannery workers' locals with 7600 per capita tax paying members; however, a request for an international union charter was denied. Apparently the A. F. of L. authorities were not convinced that the proposed international union would be capable either of financial independence or of competent leadership from within its own ranks. ${ }^{12}$ Partly as a result of this rebuff, the delegates of agricultural unions, meeting in Denver in July 1937, with those of the unions of packing house and cannery workers, 99 in all, from 22 states, agreed to unite under the auspices of the Committee for Industrial Organization as the United Cannery, Agricultural, Packing and Allied Workers of America. The policies of this organization have yet to be developed.

During recent years there has been a sharp increase in the number of labor controversies in the agricultural field, particularly in the specialized crop areas. In 1927 there were two strikes, involving 322 agricultural workers, in 1928 , four, involving 4 Io workers. In 1933 , however, the number rose to 47 , with 58,70 I workers concerned. During the period $1934-36$, there were, on the average, 29 agricultural strikes reported annually, in which an average of 25,000 workers participated. Of the total of 157 strikes reported during the period 1927-I936, II4 occurred among fruit, vegetable and truck crop workers and ten among workers in the cotton fields. Seven of these involved five thousand or more workers. Of the total, ror took place on the Pacific Coast and, of these, $8 \mathrm{r}$ in California. Many of these strikes have been characterized by extreme bitterness on both sides; they offer eloquent testimony to the reality of the agricultural labor problem in the special crop areas.

\section{Legal Disabitities of Farm Labor}

The tendency of legislatures, both national and state, to deny farm laborers legislative protection is due, first, to a belief that the actuarial and administrative difficulties would give rise to administrative costs so high as to be prohibitive; second, to a fear that the small farmer would be placed at a disadvantage; third, to a tradition that the farm hand does not require protection; fourth, to a fear that inclusion of farm laborers would mean defeat of any labor legislation proposed; and finally to

${ }^{3}$ Am. Fed. of Lhbor, Procendings 56th Anndal Convention, 587. 
lack of well organized labor support. This tendency is not peculiar to the United States. Only in England has the farm hand attained a degree of legislative protection at all comparable with that of the industrial worker. ${ }^{13}$

As regards federal legislation, farm labor was not subject to the codes set up under the National Industrial Recovery Act of 1933 and was expressly affected by the Agricultural Adjustment Act only under the provisions of the Jones-Costigan Sugar Amendment of $1934^{14}$ Neither the Social Security Act nor the National Labor Relations Act have to do with farm labor.

In connection with such exclusion from the scope of federal legislation, the development of mechanized methods of sorting, packing and processing farm products, and the growth of cooperative associations of producers to carry on such operations, create the perplexing problem of drawing a line between agricultural and nonagricultural labor. In I934 a definition drafted by Dr. Leo Wolman, Chairman of the Labor Advisory Board of the National Recovery Administration, was given official character. ${ }^{15}$ It read as follows:

"Agricultural workers are all those employed by farmers on the farm when they are engaged in growing and preparing for sale the products of the soil and/or livestock; also all labor used in growing and preparing perishable agricultural commodities for market in original, perishable, fresh form. When workers are employed in processing farm products or preparing them for market, beyond the stage customarily performed within the area of production, such workers are not to be deemed agricultural workers."

Subsequently, there were differences of opinion as to what constituted the "area of production" in agriculture,-whether, for instance, the washing, sorting, and packing of fruit, when done, not on the farm premises, but in a warehouse, were to be classified as agricultural or industrial labor. Under the Social Security Act, according to the regulations of the Bureau of Internal Revenue, the term "agricultural labor" is limited to services performed by employees of the owner or tenant on the particular farm on which crops in their raw or natural state were produced and harvested. Where such services are performed by employees of an association of producers, even though the crops were produced by the members of the association, the labor is not excepted from the taxing provisions of the act. ${ }^{16}$ In protest against such strict construction of the law, agricultural producers desired to have written into the proposed Fair Labor Standards Act of 1937 a more inclusive definition of agricultural labor. ${ }^{17}$

Under the labor laws of the several states farm labor is quite generally excepted. The detailed provisions, and the regulations for their administration, offer an intim-

" HowARD, LABOUR in AgrICULture (1935) 71, 79.

Is Ham, Sugar Beet Field Labor under the A.A.A. (May 1937) 19 J. of FarM EcoN., 643-647.

${ }^{15}$ N.R.A., Release No. 2781 , Jan. 17, 1934 .

${ }^{18}$ U. S. Treasury, Bureau of Internal Revenue, Regulations 90 (1936), 7-8, 41; 60 Market Growers J. (No. 10) 268.

${ }^{27}$ Joint Hearings before the Senate Committee on Education and Labor and the House Committee on Labor, on S. 2475 and H.R. 7200, 75th Cong., Ist Sess. (1937) Pt. 3, 1002, 1084, 1119, 1164. 
idating array which has not yet been authoritatively compiled. As regards unemployment insurance, up to April, I937 all of the state laws approved by the Social Security Board excluded agricultural labor from compulsory coverage. Twenty-eight states, however, permitted farm employers to elect to come under the act. In nearly all the states old age assistance and aid to dependent children are applicable to agricultural laborers on the basis of certain state requirements. Laws regulating the hours of work of women and their wages do not apply to agriculture, although in six states commissions appear to have some power to set standards, and the Wisconsin wage law applies generally. The workmen's compensation laws of i7 states exclude agricultural workers, but in some of the remaining 29 states with such laws workers engaged in certain extrahazardous farm tasks are required to be insured. In three states compensation insurance for agricultural workers is elective, while in most of the others farmers may voluntarily take out such insurance. ${ }^{18}$ Laws specifying that wages shall be paid at stated intervals apply to agricultural workers in California and Massachusetts; in nine others the Labor Department is authorized to take wage claim assignments and sue for their collection on behalf of workers. In a few states, there are lien holders laws which apply to specified classes. Fifteen states exempt agriculture from minimum age provisions relating to employment of minors, while the remainder do not permit the employment of children in agricultural pursuits during school hours.

In this connection it may be noted that the 56th Convention of the American Federation of Labor in 1936 unanimously adopted a resolution urging the removal of all exemptions relating to agricultural workers and their families from existing federal and state legislation and instructing its national legislative committee "to secure equality of rights for agricultural workers with industrial workers in all pending social and labor legislation which it initiates and supports."19

\section{Means of Improvement}

The foregoing sketch of the economic position of the farm laborer and of his status under existing legislation. indicates that certain aspects of his situation deserve more attention than has been given them. Particularly where migratory laborers are required in large numbers the problem is one of some magnitude. As Professor Adams of California has pointed out, agricultural enterprise cannot proceed indefinitely on the assumption that the army of seasonal workers needed at peak times must and will be available without further concern on the part of the growers. If other industries cannot give employment during off-farm season, it is doubtful whether the state should be called upon to subsidize agriculture by providing a livelihood for the unemployed. The alternative would appear to be a reorganization of agriculture with a view to the introduction of crop sequences which will reduce

\footnotetext{
${ }^{28}$ Folsom, Workmen's Compensation Acts and Agricultural Laborers (April 1937) THE AGRIcULtURAL Situation (U. S. Dep't Agric.) 9.

${ }^{2}$ Am. Fed. of Labor, Proceedings 56th Anneal Convention, 287, 640.
} 
seasonal labor needs. Indeed nature, through a process of soil depletion, may force this change. ${ }^{20}$

Aside from this geographically limited problem, it is evident that whatever increases the income of the farmer will increase that of his employees. Despite the skepticism which now, in some quarters, attaches to the theory that gains of employers inevitably filter through, at least in part, to their employees, it seems clear that farm income and wage rates are closely linked. A more effective organization of agricultural enterprise, both in its individual and collective aspects, is, therefore, a necessity if the lot of the farm laborer is to be improved. In this connection thought must be given to the extension of the demand for labor through a twelve-month period, to better methods of labor distribution and to more efficient labor management. The result will be to increase employment, reduce turnover and make the laborer a more highly valued and therefore better paid man.

In the field of federal legislation, more attention needs to be devoted to the extension to farm laborers, and to their employers, of the benefits of such plans for general social improvement as those at present under the jurisdiction of the Social Security Board. The difficulties in the way of inducing the states to apply unemployment insurance to agricultural laborers are obvious, but there would seem to be no serious administrative obstacle to the inclusion of large scale farms. Workmen's compensation laws should, as far as practicable, include agricultural employments, to which end the federal authorities should cooperate in securing greater uniformity and more satisfactory standards. If health insurance seems at present impracticable, there should be further effort to improve public health work in rural areas, provide collectively for medical aid and services, and promote rural child welfare and maternal health. Special attention should be given to the needs of children of migratory farm workers. Although plans for subsistence homesteads are at present under a cloud, there still are possibilities worth investigation of returning to the land agricultural laborers of rural background and experience, especially migratory workers who have been displaced from their farms by drought or depression. In view of the interstate character of much migratory farm labor, many persons in the states affected feel that the setting up of camps, similar to those established by the Resettlement Administration in California, should be promoted by the federal government. One of the most useful things that could be done. would be the improvement of the system of federal and state employment exchanges and the development of a well-trained personnel.

At present the only group of laborers in whose behalf the Secretary of Agriculture is authorized, under the farm program, to take limited action is that of the laborers in the sugar beet and cane fields. If practicable, it would be desirable that certain minimum labor standards should be embodied in marketing agreement and agricultural adjustment and conservation programs, as a condition of payment of benefits by the government. Since such programs are voluntary, there is, of course, the

${ }^{\infty}$ Adams, op. cit. supra note $5, \mathrm{II}, \mathrm{I} 2$. 
danger that inclusion of labor provisions would reduce participation and complicate or impede operation. The possibilities in this field deserve to be carefully considered, for by this means, if practicable, some of the more serious evils, in packing and processing plants and in the open fields, such as child labor, lack of sanitation, and excessive hours, might be dealt with.

Upon the states, however, rests the primary responsibility for improving the status of agricultural laborers since, by judicial decision, the regulation and control of agricultural production, "a purely local activity," are, like the regulation of wages and hours of labor in a local business, beyond the powers delegated to the federal government. ${ }^{21}$ The brief survey of state labor legislation indicated the need for greater inclusiveness and higher standards as regards provision for old age, unemployment insurance, workmen's compensation, regulation of child labor, health maintenance and the like. How this can be brought about,-whether by federal assistance, pressure of organized labor or the processes of education and agitation,remains to be determined. In all the agricultural states the employment service should be expanded and improved, and more effective methods of cooperation with the federal service devised. In those areas where the migratory seasonal laborers are a necessity there is an especial responsibility to see to it that the workers have decent camping facilities, public or private, and that proper standards of sanitation are maintained. To the social importance of more adequate provision of educational opportunities for the children of migratory workers reference has already been made. The rapid increase in recent years of labor organization and agricultural strikes suggests the urgent necessity of working out methods of wage determination by joint conference of employers and employed and of providing facilities, possibly under the auspices of the state departments of labor, for mediation and conciliation in farm labor disputes. In certain counties of California an auspicious beginning in this direction has been made and there has been considerable discussion of the possibility of a state board of conciliation for agriculture. When strikes of agricultural workers do occur, it is essential, as was noted by the President's Committee on Farm Tenancy, that the civil liberties of the workers, and the right of peaceful assembly and of organization, be preserved. ${ }^{22}$

The possibilities of improvement of the status of farm labor through independent action on the part of organized producers and laborers remain to be explored. As yet little has been done in this field. In some areas there is gratifying evidence that associations of producers are beginning to concern themselves with other aspects of the labor problem than that of providing an adequate supply of cheap labor. It is important that such associations should assume more responsibility for the social 'effects of the methods of labor utilization and management in vogue; otherwise, they can hardly escape intervention from agencies outside the industry, or the growth of militant, if sporadic, organizations of labor within it. Just what can be

${ }^{21}$ U. S. v. Butler, 297 U. S. I (1936).

Farm Tenancy, Report of the President's Comaitte (1937) 19. 
accomplished by associations of laborers in the agricultural field, organized on a national basis, remains to be seen. In most countries experience indicates that either the organized labor movement in industry must be willing, as in pre-Nazi Germany, to support generously, and for a protracted period, the effort to organize farm laborers, or else the agricultural workers must have the aid of some such governmental bodies as the conciliation authorities in Germany or the agricultural wages board in England. In this connection the recent entry of the Committee for Industrial Organization into the farm labor field is of interest. Supported in some such way, unions of farm laborers may prove to be an aid in improving and stabilizing employment relations, especially on the big farms in the special crop areas. Any considerable and general increase in income, however, will depend upon a better and more productive organization of agriculture.

Indispensable to any improvement of the laborers' status is the necessity, alluded to by the President's Committee on Farm Tenancy, of more social and economic data on the farm worker's present position. ${ }^{23}$ In most farm studies, labor is regarded simply as an expense item. Wage data are so generalized as to be of little value for specific purposes; satisfactory income data are almost non-existent. Information on the demand for labor and the supply of it in particular areas is lacking. There is no adequate knowledge of housing and camp facilities. And yet without such information the formulation of even the simplest measures for stabilization of the labor supply, regulation of the movement of labor to crop areas, avoidance of excessive spreading of employment with resulting low earnings, and scientific administration of relief and rehabilitation of the marginal labor groups is well-nigh impossible. In this field, there is need for the active cooperation of federal and state agencies in labor and agriculture, proceeding in the spirit expressed by a special committee of the agricultural colleges: "The solution of the problems of agriculture does not lie in the direction of putting on the land those workers who will take the wage which a low yield affords, but rather in raising the yield to the level which high wage men demand."

${ }^{20}$ Id. at 15 . 